\title{
AGE AND GROWTH OF LARGE SCALE SCRAPER (CAPOETA ACULEATA) IN THE GIZEHRUD RIVER, TIGRIS BASIN
}

\author{
Yazdan Keivany* and Vali Mohamadiyani
}

Department of Natural Resources (Fisheries Division), Isfahan University of Technology, Isfahan 84156-83111, Iran

*Corresponding author. Email: Keivany@iut.ac.ir

\author{
Article history \\ Received: 27 March 2021; \\ accepted: 4 May 2021
}

Keywords:

Age; Cyprinidae; growth models; von Bertalanffy

\begin{abstract}
The large scale barb, Capoeta aculeata is a little known species native to Iran. Its age and growth were studied in 377 specimens collected monthly from the Gizehrud River in Lorestan Province (Tigris basin) during May 2014-May 2015. Sex ratio was 1M:2.1F. The maximum age of both female and male specimens was $6^{+}$years. The most common age group of both male and female fish was $4^{+}$. The fork length ranged from 12.2 to $20.8 \mathrm{~cm}(17.4 \pm 1.2 \mathrm{SD})$ and weight from 32 to $188 \mathrm{~g}(93.6 \pm 21.8 \mathrm{SD})$. The estimated length-weight relationship of male specimens was $\mathrm{W}=$ $0.0161 \mathrm{FL}^{3.012},\left(\mathrm{r}^{2}=0.82\right)$ and that of female specimens $\mathrm{W}=0.0248 \mathrm{FL}^{2.87},\left(\mathrm{r}^{2}=0.79\right)$. This relationship showed that growth of both Capoeta aculeata sexes was isometric. The estimated von Bertalanffy growth model for males was $\mathrm{Lt}=20.9\left[1-\mathrm{e}^{-0.57(\mathrm{t}+0.2)}\right]$ and for females $\mathrm{Lt}=20.3\left[1-\mathrm{e}^{-0.56(\mathrm{t}-0.8)}\right]$. The growth performance index was estimated at 5.4 and 5.5 for males and females, respectively, indicating a similar growth rate for both sexes.
\end{abstract}

\section{INTRODUCTION}

The genus Capoeta with 12 species in Iran is one of the most important native cyprinid fishes. The large scale barb or scraper, Capoeta aculeata (Valenciennes, 1844), is widely distributed in such Iranian river basins as the Tigris (the Karun and the Karkheh Rivers), Fars, Isfahan, Kavir, Kerman and the Namak (Keivany et al. 2016; Esmaeili et al. 2017). There are several studies on biology of $C$. damascina (Khalaf 1987; Fishelson et al. 1996; Abdoli and Mostafavi 2009; Gharache 2008; Asadollah et al. 2011, 2017; Siami et al. 2017), C. fusca (Patimar and Mohamadzadeh 2010), C. trutta (Poria et al. 2014a, b), C. capoeta (Abdoli et al. 2008; Patimar et al. 2009) and C. coadi (Keivany and Siami 2020). Although Capoeta aculeata is consumed by locals, its biology is not well documented, because of its low density and lack of commercial importance.

Growth is one of the most important features of fish biology, especially in economically important species. Growth information could be used for multiple purposes, e.g., stock assessment, aquaculture and protection (Kiani et al. 2016; Keivany et al. 2017, 2018). Fish growth is affected by several factors, e.g., temperature, dissolved oxygen, salinity and their interaction. The aim of this study was to investigate the growth biology of $C$. capoeta in the Gizehrud River, a tributary of the Karkheh River (Tigris basin), in Lorestan province, the west-center of Iran, as one of the important habitats for the species, based on such parameters as age and length composition, length-weight relationship (LWR) and van Bertalanffy parameters.

\section{MATERIALS AND METHODS}

A total of 377 specimens were collected by monthly sampling with a cast net ( $2 \mathrm{~cm}$ mesh size) from the Gizehrud River (Table 1) in Lorestan Province, western Iran $\left(34^{\circ} 08^{\prime} 01^{\prime \prime} \mathrm{N}, 47^{\circ} 49^{\prime} 18^{\prime \prime} \mathrm{E}\right)$, a tributary of the Karkheh River in the Tigris basin of Iran, from July 2014 to June 2015. Fish samples were anesthetized in $1 \%$ clove oil, fixed in 10\% neutralized formalin and transported to the laboratory. Standard (SL), fork (FL) and total lengths (TL) were measured to the nearest $0.1 \mathrm{~mm}$ and the total weight to the nearest $0.01 \mathrm{~g}$. For fish age determination, scales and the whole transparent sagittal otoliths were taken out and age reading was carried out by three fish age-readers and the coinciding readings were recorded to validate the ageing (Biswas 1993; Johal et al. 2001). All the procedures were carried out in accordance with the accepted procedural protocol employed by the Iranian Department of Environment. Also, the back calculation was performed using the following equation (Johal et al. 2001).

$$
L_{n}=\left(S_{n} / S\right) \times(L-a)+a
$$

where $\mathrm{L}_{\mathrm{n}}=$ length of the fish at a specific age $(\mathrm{mm}), \mathrm{L}=$ fish length $(\mathrm{mm}), \mathrm{S}_{\mathrm{n}}=$ radius of the annulus, $\mathrm{S}=$ total radius of the scale $(\mathrm{mm})$ and $\mathrm{a}=$ intercept of the length-scale radius regression equation. Upon examination of the type of relationships between SL and scale diameter, the Fraser-Lee model was used for back-calculating the corresponding lengths attained in the previous years of life. This method is believed to describe the linear body-scale relationship accurately (Ricker 1975; Klumbs et al. 1999). 


$$
\mathrm{Sli}=\mathrm{c}+(\mathrm{SL}-\mathrm{c}) \times(\mathrm{Si} / \mathrm{S})
$$

where $\mathrm{SLi}=$ the standard length of the fish when annulus i was formed, $\mathrm{SL}=$ the standard length at the time of capture, $\mathrm{Si}=$ the distance from the scale focus to the annulus $\mathrm{i}, \mathrm{S}=$ the total scale radius, and $\mathrm{c}$ is the intercept (correction term) on the length axis of the linear regression between SL and S. The von Bertalanffy growth parameters were calculated using:

$$
\begin{aligned}
\mathrm{L}_{\mathrm{t}} & =\mathrm{L}_{\infty}\left[1-\mathrm{e}^{-\mathrm{K}(\mathrm{t}-\mathrm{t})} 0\right] \text { for FL and } \\
\mathrm{W}_{\mathrm{t}} & =\mathrm{W}_{\infty}\left[1-\mathrm{e}^{-\mathrm{K}(\mathrm{t}-\mathrm{t})} 0\right]^{\mathrm{b}} \text { for weight }
\end{aligned}
$$

where $\mathrm{L}_{\mathrm{t}}$ length of fish in $\mathrm{cm}$ at age $\mathrm{t}, \mathrm{L}_{\infty}=$ asymptotic fish length in $\mathrm{cm}, \mathrm{e}=$ base of natural $\log (2.71828), \mathrm{t}=$ fish age (year), $\mathrm{t}_{0}=$ hypothetical time at which the length of the fish was zero, $\mathrm{K}=$ rate at which the growth curve approaches the asymptote, $\mathrm{W}_{\mathrm{t}}=$ weight of the fish in grams at age $\mathrm{t}, \mathrm{W}_{\infty}=$ asymptotic weight of the fish in grams and $\mathrm{b}=\mathrm{a}$ constant in the length-weight relationship (Ricker 1975; Sparre et al. 1989). $t_{0}$ (year) and $k$ were estimated using the $\mathrm{L}_{\infty}$ and plotting the equation $-\ln \left(1-L_{t} / L_{\infty}\right)$ against the age $(t)$, where $\mathrm{k}=$ regression slope and $t_{0}=$ $-a / b$ (Bertalanffy 1938). The length-weight relationship (LWR) was calculated according to the formula:

$$
\mathrm{W}=\mathrm{aL}^{\mathrm{b}}
$$

where $\mathrm{W}=$ weight of fish $(\mathrm{g}), \mathrm{L}=$ total length $(\mathrm{cm}), a=$ Intercept and $b=$ the slope of the regression line. The strength of LWR was evaluated by means of regression coefficient $\left(\mathrm{r}^{2}\right)$. The growth pattern in both sexes was determined using the following model (Pauly 1984):

$$
t=\frac{s d \ln L_{f}}{s d \ln W_{t}} \times \frac{|b-3|}{\sqrt{1-r^{2}}} \times \sqrt{n-2}
$$

where sd $\ln \mathrm{L}_{\mathrm{f}}=$ the standard deviation of the natural logarithm of the fork length, sd $\ln \mathrm{W}_{\mathrm{t}}=$ the standard deviation of the natural logarithm of the body weight, $\mathrm{b}=$ the slope, calculated from the length and weight relationship. Growth performance index (phi-prime index) $\varphi$ ` was computed using the following equation (Munro and Pauly 1983; Pauly and Munro 1984):

$$
\varphi^{`}=\mathrm{Lnk}+2 * \mathrm{LnL}_{\infty}
$$

Condition coefficients were calculated for both sexes using the equation (Ricker 1975):

$$
\mathrm{K}=\left(\mathrm{W} / \mathrm{FL}^{3}\right) * 100
$$

W $\infty$ was estimated by replacing length by $L \infty$ and $b$ by 3 . The condition factor was calculated according to the formula (Hile 1936):

$$
\mathrm{CF}=(\mathrm{W} / \mathrm{L} 3) \times 100
$$

Where $\mathrm{CF}=$ condition factor, $\mathrm{W}=$ total body weight $(\mathrm{g})$ and $\mathrm{L}=$ Total length $(\mathrm{cm})$. The relative length of gut was calculated following Al-Hussaini (1949) as:

\section{$\mathrm{RLG}=\mathrm{Li} / \mathrm{FL}$}

where $\mathrm{RLG}=$ Relative length of gut, $\mathrm{Li}=$ gut length $(\mathrm{cm})$ and $\mathrm{TL}=$ Total length $(\mathrm{cm})$. The feeding intensity was calculated following Desai (1970) as:

$$
\mathrm{FI}=\mathrm{Wi} / \mathrm{W}
$$

where FI = feeding intensity, $\mathrm{Wi}=$ gut weight $(\mathrm{g})$ and $\mathrm{W}=$ total body weight $(\mathrm{g})$. For estimating the longitudinal growth, the length increase in both sexes was calculated separately. To determine mass growth, first, the mean length was transformed to mean weights using the LWR, and then the spontaneous growth was calculated according to:

$$
R=\operatorname{Ln}\left(W_{(t+1)}\right)-\operatorname{Ln}\left(W_{(t)}\right) / \Delta t
$$

where $\mathrm{r}=$ specific growth, $\mathrm{W}_{(\mathrm{t}+1)}$ mean weight of fish at $(t+1)$ year, $W_{t}=$ mean weight of fish at $t$ year and $\Delta t=$ time difference between $t$ year and $t+1$ year, which is

\begin{tabular}{|c|c|c|c|}
\hline $\mathrm{FL} \pm \mathrm{SD}$ & No. & Sex & Months \\
\hline $17.63 \pm 0.91$ & 6 & Male & \multirow[t]{2}{*}{ July } \\
\hline $17.35 \pm 1.09$ & 24 & Female & \\
\hline $17.18 \pm 1.04$ & 15 & Male & \multirow[t]{2}{*}{ August } \\
\hline $17.66 \pm 1.03$ & 15 & Female & \\
\hline $17.37 \pm 1.03$ & 10 & Male & \multirow[t]{2}{*}{ September } \\
\hline $18.11 \pm 0.82$ & 22 & Female & \\
\hline $17.80 \pm 1.03$ & 8 & Male & \multirow[t]{2}{*}{ October } \\
\hline $17.82 \pm 0.67$ & 23 & Female & \\
\hline $16.76 \pm 0.67$ & 8 & Male & \multirow[t]{2}{*}{ November } \\
\hline $17.80 \pm 1.15$ & 24 & Female & \\
\hline $16.12 \pm 0.63$ & 8 & Male & \multirow[t]{2}{*}{ December } \\
\hline $17.70 \pm 0.85$ & 24 & Female & \\
\hline $17.10 \pm 0.87$ & 11 & Male & \multirow[t]{2}{*}{ January } \\
\hline $17.10 \pm 0.65$ & 21 & Female & \\
\hline $17.00 \pm 0.44$ & 9 & Male & \multirow[t]{2}{*}{ February } \\
\hline $16.85 \pm 0.64$ & 22 & Female & \\
\hline $16.55 \pm 0.81$ & 12 & Male & \multirow[t]{2}{*}{ March } \\
\hline $17.74 \pm 1.05$ & 20 & Female & \\
\hline $17.00 \pm 0.59$ & 12 & Male & \multirow{2}{*}{ April } \\
\hline $18.00 \pm 1.60$ & 20 & Female & \\
\hline $18.90 \pm 1.48$ & 7 & Male & \multirow[t]{2}{*}{ May } \\
\hline $18.82 \pm 0.90$ & 25 & Female & \\
\hline $15.50 \pm 1.35$ & 14 & Male & \multirow[t]{2}{*}{ June } \\
\hline $16.50 \pm 1.76$ & 17 & Female & \\
\hline $16.69 \pm 1.19$ & 120 & Male & \multirow{2}{*}{ Average } \\
\hline $17.65 \pm 1.14$ & 257 & Female & \\
\hline
\end{tabular}
usually considered to be one year.

For comparisons of two means, $t$-test, and for multiple comparison of means, one-way ANOVA followed by Duncan posthook test at $95 \%$ confidence level was used. Chi square test was used for comparing the sex ratio. Statistical analyses were carried out using SPSS 20 and Excel 2016 computer software.

Table 1. Number of Capoeta aculeata specimens caught in the Gizehrud River in different months (2014-2015). 


\section{RESULTS}

A total of 377 fish were examined, 120 (30\%) of which were male and 257 (70\%) female specimens. The overall sex ratio of males to females was $1 \mathrm{M}: 2.1 \mathrm{~F}$ and the performed Chi-square analysis showed a significant difference from the $1: 1$ ratio $\left(\chi^{2}=12.64, p<0.05\right)$. The fork length ranged from 8.94 to $42.95(23.32 \pm 6.53 \mathrm{SD})$ $\mathrm{cm}$ and weight from $10.3-1255.5(242.59 \pm 213.5) \mathrm{g}$. The majority of fish were in the body length range of 17.0-19.5 cm (Table 2, Fig. 1). The maximum age of both male and female specimens was $6^{+}\left(3^{+}-6^{+}\right)$years (Fig. 2), and the most common age group was $4^{+}$.

The smallest mature males and females were in the $12.0-14.5 \mathrm{~cm}$ length class (the fork length of the smallest mature male was $12 \mathrm{~cm}$ and that of the smallest mature female $14 \mathrm{~cm}$ ) (Table 2). Since all the specimens were mature and older than 3 years, it was not feasible to estimate the mean age at first maturity. Females had a wider length range and were larger than the males $(p<$ 0.05) (Tables 1-3 and Fig. 3).

In all age groups, the back calculated lengths were greater than the observed lengths (Table 4). The calculated length-weight relationship for males was $\mathrm{W}=0.0161 \mathrm{FL}^{3.01}\left(\mathrm{r}^{2}=0.82\right)$ and for females $\mathrm{W}=$ $0.0248 \mathrm{FL}^{2.87}\left(\mathrm{r}^{2}=0.80\right)$, indicating an isometric growth pattern for males and a negative allometric growth pattern for females (Figs 3-4).

The growth performance index was higher in the females indicating their faster growth (Table 5). The mean condition factor did not differ significantly between the two sexes and among different age classes, although in some months, it differed significantly $(\mathrm{F}=5.62, p<$ 0.05 ). The highest value (1.9) of the condition factor of male specimens was recorded in May and the lowest in June (1.5), and the highest value (2.1) of females was observed in May and the lowest in August (1.6) (Fig. 5). Spontaneous growth of fish was observed to decrease with fish age (Table 5).

The estimated age-length relationships in males were $\mathrm{L}_{\mathrm{t}}=20.94\left[1-\mathrm{e}^{-0.57(\mathrm{t}+0.2)}\right]$ and in females $\mathrm{L}_{\mathrm{t}}=20.3\left[1-\mathrm{e}^{-0}\right.$ $.56(t+0.8)$ ] (Fig. 3). The age-weight relationships in males and females were $\mathrm{W}_{\mathrm{t}}=1242.85\left[1-\mathrm{e}^{-0.205(\mathrm{t}+0.586)}\right]^{2.82}$, and $\mathrm{W}_{\mathrm{t}}=3357.5\left[1-\mathrm{e}^{-0.162(\mathrm{t}+0.208)}\right]^{2.92}$, respectively (Fig. 6). The spontaneous growth rate of males was estimated at 0.19 and that of females at 0.15 indicating a faster growth rate for the males.

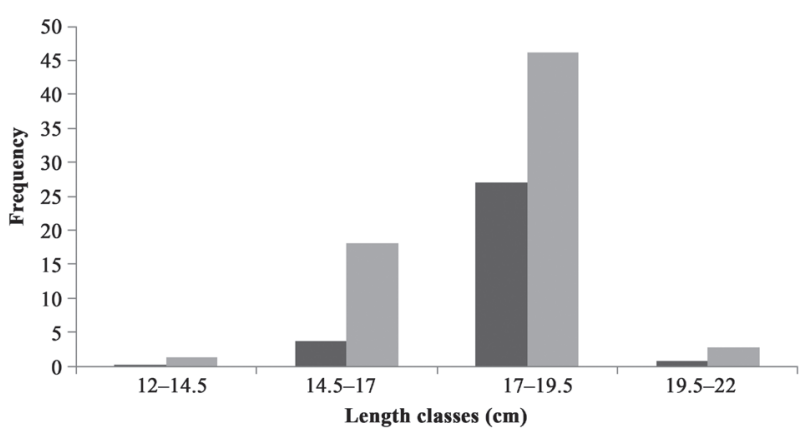

Figure 1. Length frequency of Capoeta aculeata males (dark) and females (light) in the Gizehrud River in 2014-2015.

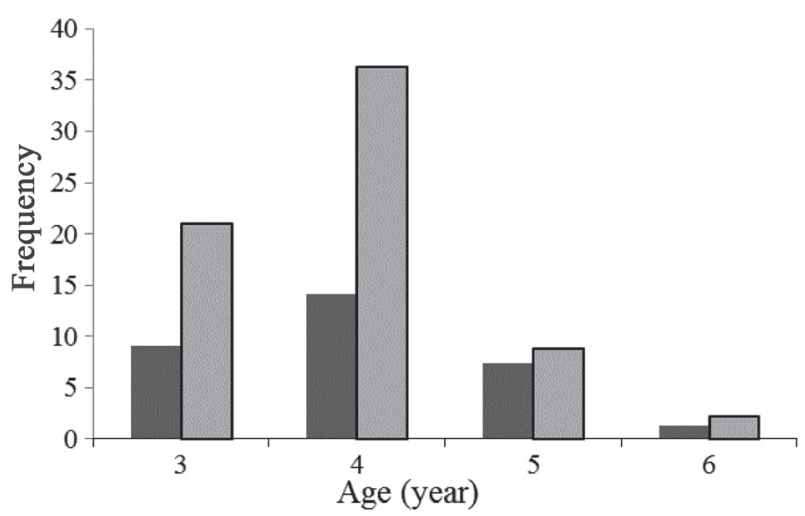

Figure 2. Age frequency of Capoeta aculeata males (dark) and females (light) in the Gizehrud River in 2014-2015.

Table 2. Length and weight of Capoeta aculeata in the Gizehrud River in 2014-2015.

\begin{tabular}{|l|l|l|l|l|l|}
\hline \multirow{2}{*}{ Sex } & \multirow{2}{*}{ No. } & \multicolumn{2}{|c|}{ FL $(\mathrm{cm})$} & \multicolumn{2}{c|}{ Weight $(\mathrm{g})$} \\
\hline Male & 120 & $12-21$ & $17 \pm 1.2$ & $159-32$ & $20 \pm 84$ \\
\hline Female & 257 & $14-21$ & $18 \pm 1.1$ & $188-47$ & $21 \pm 98$ \\
\hline All & 377 & $12-21$ & $17.4 \pm 1.2$ & $188-32$ & $21.81 \pm 93.55$ \\
\hline
\end{tabular}

Table 3. Length of Capoeta aculeata at different ages in the Gizehrud River in 2014-2015.

\begin{tabular}{|c|l|c|c|}
\hline Age & \multicolumn{1}{|c|}{ Sex } & No. & Mean fork length \\
\hline \multirow{2}{*}{$3^{+}$} & Male & 34 & $16.2 \pm 1.19$ \\
\cline { 2 - 4 } & Female & 79 & $16.9 \pm 1.04$ \\
\hline \multirow{2}{*}{$4^{+}$} & Male & 53 & $17.1 \pm 0.84$ \\
\cline { 2 - 4 } & Female & 137 & $17.8 \pm 1.01$ \\
\hline \multirow{2}{*}{$5^{+}$} & Male & 28 & $17.2 \pm 0.96$ \\
\cline { 2 - 4 } & Female & 33 & $18.3 \pm 0.72$ \\
\hline \multirow{2}{*}{$6^{+}$} & Male & 5 & $19.6 \pm 1.05$ \\
\cline { 2 - 4 } & Female & 8 & $19.4 \pm 0.85$ \\
\hline
\end{tabular}

Table 4. Back-claculated and observed lengths of Capoeta aculeata at different ages in the Gizehrud River in 2014-2015.

\begin{tabular}{|l|l|c|c|c|c|c|c|}
\hline Sex & Fork length & $1^{+}$ & $2^{+}$ & $3^{+}$ & $4^{+}$ & $5^{+}$ & $6^{+}$ \\
\hline \multirow{2}{*}{ Males } & Observed & - & - & $20.63 \pm 2.7$ & $17.1 \pm 0.84$ & $18.3 \pm 0.72$ & $19.4 \pm 0.85$ \\
\cline { 2 - 8 } & Back-calculated & $4.72 \pm 1.56$ & $8.87 \pm 2.04$ & $12.9 \pm 2.54$ & $16.06 \pm 2.97$ & $17.12 \pm 2.64$ & - \\
\hline \multirow{2}{*}{ Females } & Observed & - & - & $16.19 \pm 1.19$ & $17.1 \pm 0.84$ & $17.19 \pm 0.96$ & $19.62 \pm 1.05$ \\
\cline { 2 - 9 } & Back-calculated & $5.86 \pm 2.02$ & $9.39 \pm 2.38$ & $12.15 \pm 2.41$ & $14.87 \pm 2.53$ & $17.34 \pm 2.84$ & - \\
\hline
\end{tabular}




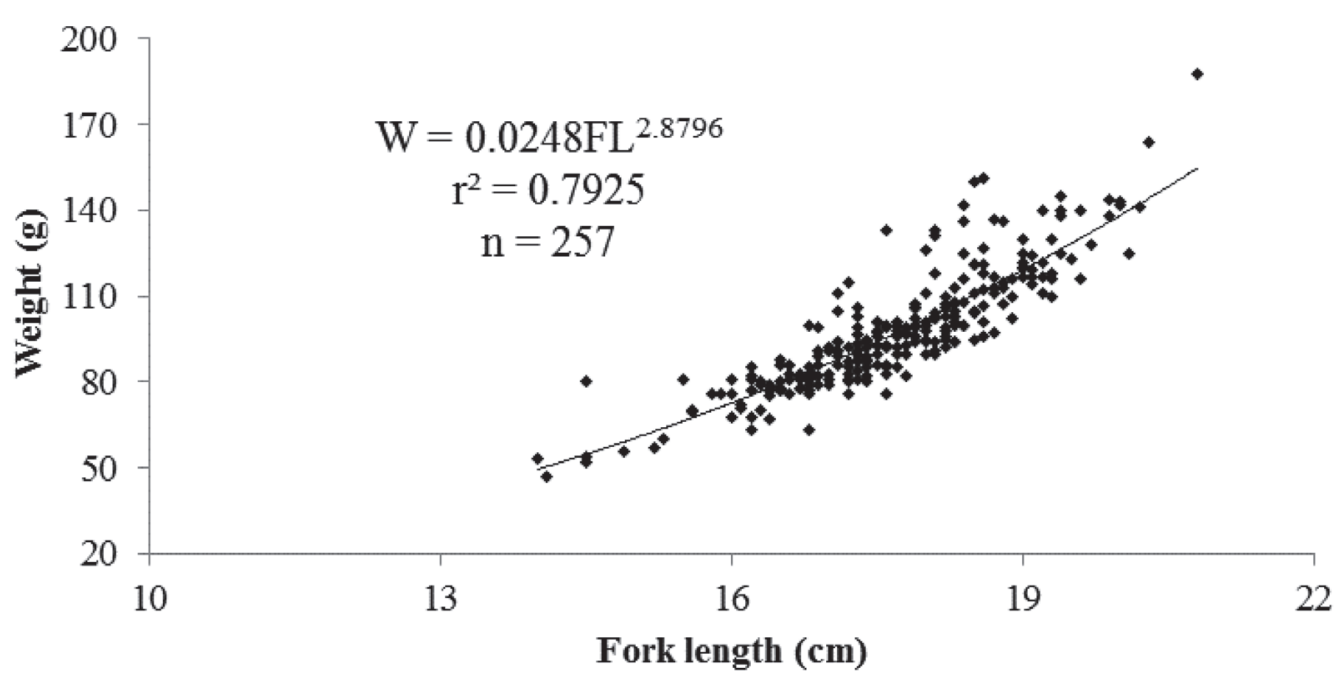

Figure 3. Length-weight relationship of Capoeta aculeata females in the Gizehrud River in 2014-2015.

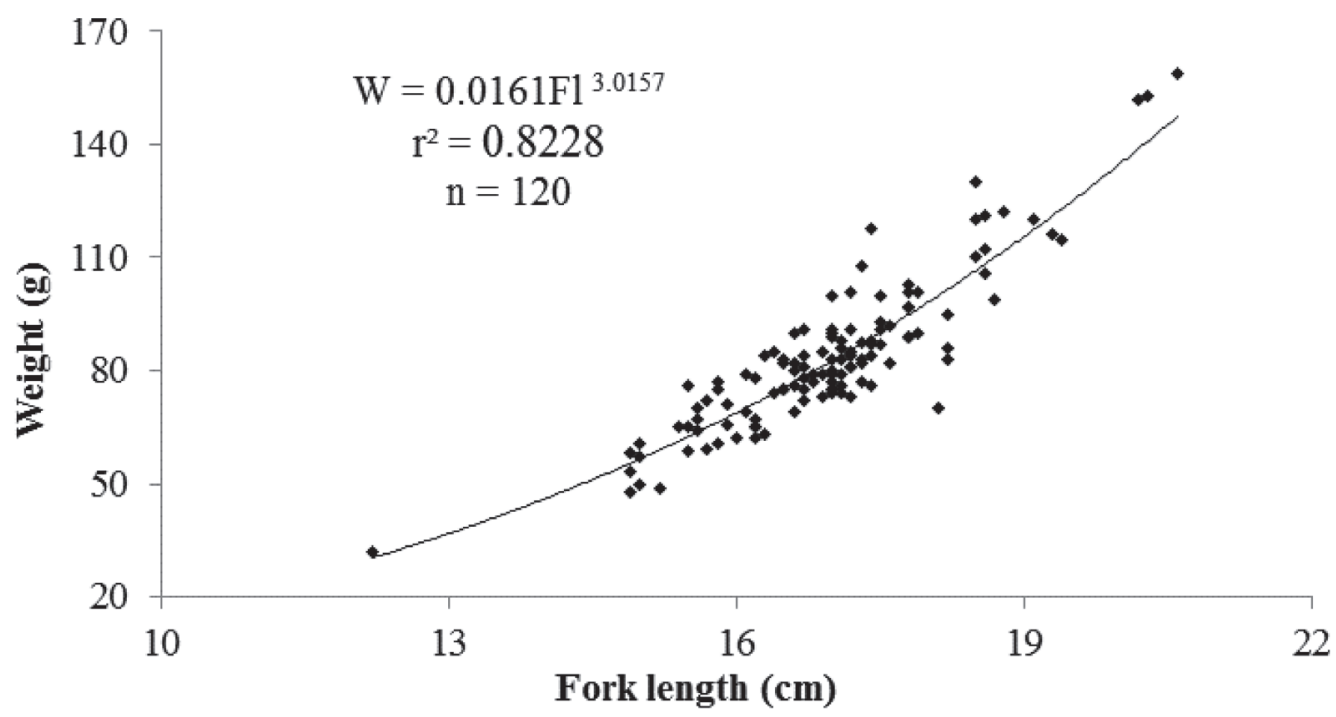

Figure 4. Length-weight relationship of Capoeta aculeata males in the Gizehrud River in 2014-2015.

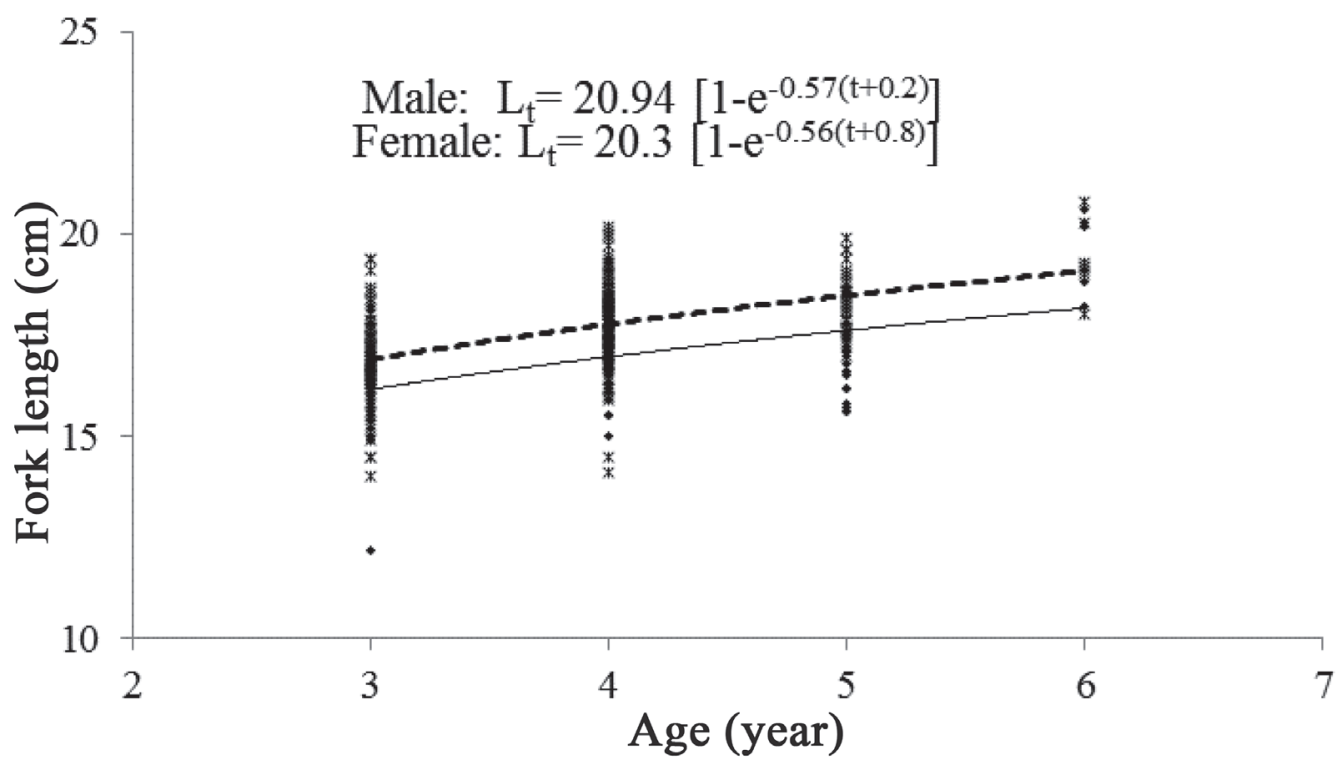

Figure 5. Age-length relationship of Capoeta aculeata males (dark) and females (light) in the Gizehrud River in 20142015. 
Table 5. Maximum age, length, weight and von Bertalanffy growth parameters reported for Capoeta spp. from different rivers.

\begin{tabular}{|c|c|c|c|c|c|c|c|c|c|c|c|}
\hline Species & Locality & Sex & $\begin{array}{c}\text { Age } \\
\text { range }\end{array}$ & \begin{tabular}{|c|} 
Max \\
weight
\end{tabular} & $\begin{array}{l}\text { Max } \\
\text { length }\end{array}$ & $\begin{array}{l}\mathrm{L} \infty \\
(\mathrm{cm})\end{array}$ & $\mathrm{t}_{0}$ & K & $\mathrm{b}$ & $\varphi$ & Reference \\
\hline \multirow[t]{8}{*}{ C. damascina } & \multirow[t]{2}{*}{ Zayandehrud } & Male & $0^{+}-8^{+}$ & & & 17.30 & & 0.23 & 2.53 & & \multirow[t]{2}{*}{ Mazaheri (2007) } \\
\hline & & Female & $0^{+}-8^{+}$ & & & 49.40 & & 0.18 & 2.73 & & \\
\hline & \multirow[t]{2}{*}{ Hanna wetland } & Male & $0^{+}-6^{+}$ & 1300 & 40 & 52.39 & -0.30 & 0.18 & 3.22 & & \multirow{2}{*}{$\begin{array}{l}\text { Soofiani and } \\
\text { Asadollah (2010) }\end{array}$} \\
\hline & & Female & $0^{+}-6^{+}$ & 1545 & 44 & 64.91 & -0.45 & 0.15 & 3.17 & & \\
\hline & \multirow{2}{*}{ Zayandehrud } & Male & $0^{+}-8^{+}$ & 690 & 39 & 40.67 & -0.47 & 0.30 & 2.94 & & \multirow{2}{*}{$\begin{array}{l}\text { Asadollah et al. } \\
(2011,2017)\end{array}$} \\
\hline & & Female & $0^{+}-10^{+}$ & 1935 & 49 & 62.61 & -0.10 & 0.14 & 2.98 & & \\
\hline & \multirow{2}{*}{$\begin{array}{l}\text { Beheshtabad } \\
\text { River }\end{array}$} & Male & $2^{+}-7^{+}$ & 595 & 35 & 35.9 & -0.50 & 0.20 & 2.82 & & \multirow[t]{2}{*}{ Siami et al. (2017) } \\
\hline & & Female & $2^{+}-8^{+}$ & 1256 & 43 & 49.30 & -0.20 & 0.16 & 2.91 & & \\
\hline \multirow[t]{6}{*}{ C. gracilis } & \multirow[t]{2}{*}{ Madarsu } & Male & ${ }^{+} 1-{ }^{+} 5$ & & & 24.90 & -0.30 & 0.22 & 3.03 & & \multirow[t]{2}{*}{ Rezaei et al. (2007) } \\
\hline & & Female & ${ }^{+} 2-{ }^{+} 8$ & & & 30.60 & -0.38 & 0.21 & 3.05 & & \\
\hline & \multirow{2}{*}{ Gorganrud } & Male & $0^{+}-3^{+}$ & & & 19.00 & -0.10 & 0.46 & 3.05 & & \multirow[t]{2}{*}{ Abdoli et al. (2008 } \\
\hline & & Female & $0^{+}-3^{+}$ & & & 23.00 & -0.70 & 0.47 & 3.05 & & \\
\hline & \multirow[t]{2}{*}{ Gorganrud } & Male & $0^{+}-4^{+}$ & & & 19.50 & & 0.54 & 2.89 & & \multirow{2}{*}{$\begin{array}{l}\text { Patimar et al. } \\
(2009)\end{array}$} \\
\hline & & Female & $0^{+}-5^{+}$ & & & 27.50 & & 0.33 & 2.95 & & \\
\hline \multirow[t]{4}{*}{ C. fusca } & \multirow{2}{*}{ Birjand Qanats } & Male & & & & & & & & & \multirow[t]{2}{*}{ Johari et al. 2009) } \\
\hline & & Female & & & 22 & & & & 2.948 & & \\
\hline & \multirow[t]{2}{*}{ Shadmehr Qanat } & Male & $1-^{+} 5^{+}$ & & & 18.70 & -0.47 & 0.33 & 2.93 & & \multirow{2}{*}{$\begin{array}{l}\text { Patimar and Moha- } \\
\text { madzadeh (2010) }\end{array}$} \\
\hline & & Female & $1-^{+} 5^{+}$ & & & 22.30 & -0.43 & 0.32 & 2.99 & & \\
\hline \multirow{6}{*}{ C. trutta } & \multirow[t]{2}{*}{ Mimeh River } & Male & $0^{+}-6^{+}$ & & & 45.86 & -1.45 & 0.15 & 2.71 & & \multirow{2}{*}{$\begin{array}{l}\text { Patimar and Farzi } \\
(2011)\end{array}$} \\
\hline & & Female & $0^{+}-6^{+}$ & & & 50.79 & -1.28 & 0.13 & 1.72 & & \\
\hline & \multirow[t]{2}{*}{ Gamasyab River } & Male & $1-{ }^{+} 5^{+}$ & 108 & 21 & & & & & & \multirow[t]{2}{*}{ Poria et al. (2014a) } \\
\hline & & Female & $1-^{+} 5^{+}$ & 329 & 31 & & & & & & \\
\hline & \multirow[t]{2}{*}{ Alvand River } & Male & $1^{+}-5^{+}$ & & 37 & & & & & & \multirow[t]{2}{*}{ Poria et al. (2014b) } \\
\hline & & Female & $1^{+}-6^{+}$ & & 38 & & & & & & \\
\hline \multirow[t]{2}{*}{ C. coadi } & Beheshtabad & Male & $2^{+}-7^{+}$ & 595 & 35 & 35.90 & -0.50 & 0.20 & 2.82 & & Keivany et al. \\
\hline & River & Female & $2^{+}-8^{+}$ & 1256 & 43 & 49.3 & -0.20 & 0.16 & 2.91 & & $(2018)$ \\
\hline C. aculeata & Ghizehrud River & Male & $+3-+6$ & 159 & 20.94 & 20.94 & -0.20 & 0.57 & 3.01 & 5.52 & Present study \\
\hline
\end{tabular}

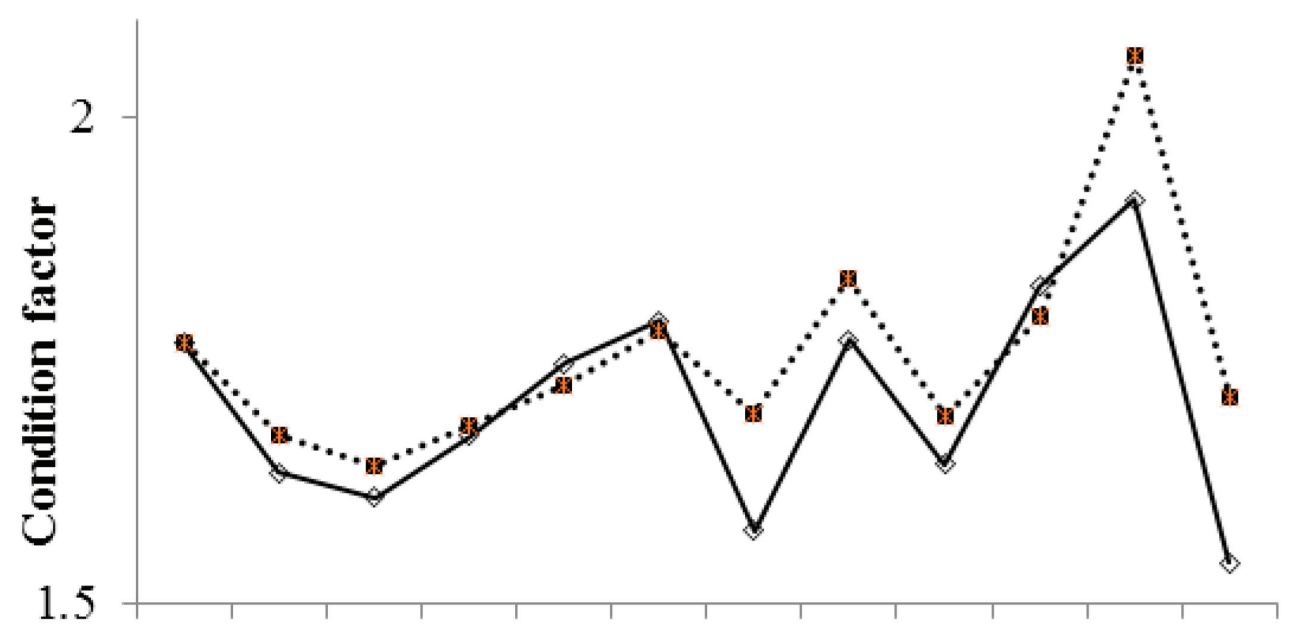

Jul Aug Sep Oct Nov Dec Jan Feb Mar Apr May Jun

\section{Months}

Figure 6. Mean condition factor variations of male (continuous line) and female (dot line) Capoeta aculeata in the Gizehrud River in 2014-2015.

The relative length of gut was 5.8 for males and 6.2 for females, indicating a herbivorous feeding habit for this species. This ratio increased from the third year to the fifth year, but significantly decreased in the sixth year $(p<0.05)$. The feeding intensity of male specimens was estimated at 6.9 and that of female specimens at 7.4, indicating a medium feeding intensity for this species. 


\section{DISCUSSION}

The maximum age of the examined C. aculeata specimens was $6^{+}$years and the most common age class was $4^{+}$. There are no data on other age groups of this species to compare with. As reported by Mazaheri (2007), the maximum age of $C$. damascina collected from the Zayandehrud River was $8^{+}$, and that reported by Soofiani and Asadollah (2010) from the Hanna Dam was $6^{+}$years. In the Zayandehrud River, the maximum age of the same fish species (a female with a fork length of $49 \mathrm{~cm}$ and weight of $1935 \mathrm{~g}$ ) recorded by Asadollah et al. (2011, 2017) was $10^{+}$, and by Kheyrandish et al. (2014) $5^{+}$ years. The maximum age reported for the congeneric species C. coadi is $8^{+}$years (Keivany and Siami 2020), and that for $C$. capoeta is $5^{+}$(Abdoli and Mostafavi 2009) (Table 5). Growth variation could be due to the adaptation to environmental changes (Nikolsky 1963). Up to the age of four years, both sexes usually exhibit the same growth rate, but later, females grow faster (Mazaheri 2007; Asadollah et al. 2011, 2017).

The length-weight relationship determined in this study implied that the growth of females was negatively allometric and that of males isometric. Soofiani and Asadollah (2010) and Asadollah et al. (2011) found that the growth of both $C$. damascina sexes is positive allometric. Hasankhani et al. (2013) found a positive allometric growth. Esmaeili and Ebrahimi (2006) reported the isometric growth pattern for $C$. damascina from the Sirvan River. However, Patimar and Mohammadzadeh (2010) reported a negative allometric growth pattern for male and an isometric pattern for female specimens of C. fusca from eastern Iran. Patimar et al. (2009) reported a negative allometric growth pattern for Capoeta gracilis. Generally, the b value fluctuates between 2.5 and 3.5 (Nikolsky 1963) and is affected by seasonal, geographical, feeding and environmental conditions.

In this species, just like in other related species (Table 5), the Lo was higher in female specimens. This difference could be due to the higher age at maturity and a longer life span of female specimens. The earlier maturity of the males leads to the slower growth of their somatic organs (Wootton 1998). However, due to natural causes such as predation, diseases and fishing, male specimens rarely reach the asymptotic length in the wild (Biswas 1993). The growth performance index of males was found to be higher indicating their faster growth rate. In different studies, different results have been achieved. Abdoli et al. (2008) reported a higher growth rate of females in the Gorganrud River and Kalkan (2008) in the Karakaya Dam. The higher growth rate means that the fish reaches the asymptotic length faster (King 1995). These parameters are influenced by temperature, salinity, dissolved oxygen and other environmental conditions, therefore vary with these factors. Besides, as temperature increases, $\mathrm{K}$ increases logarithmically and $\mathrm{L}_{\infty}$ decreases (King 1995).

The sex ratio of the studied fish in the Beheshtabad River was $1 \mathrm{M}: 2.1 \mathrm{~F}$. A similar sex ratio in C. damascina was reported by Gharacheh (2008) from the Qanat in southern Isfahan and by Stoumboudi et al. (1993) from the Jordan River. In other areas, this ratio in C. damascina was found to be in favour of females (Mazaheri 2007; Soofiani and Asadollah 2010; Asadollah et al. 2011). Differences in the sex ratio might be predetermined by the interspecific differences in abilities of fish to adapt to different ecological conditions, differences in the date and time of capture, in the fishing gear used, in location, differences in growth rates and mortalities between males and females, migration of mature fish from the region and differences in behavioral patterns of male and female fish (Qasim 1966; Pitcher and Hart 1982; Fishelson et al. 1996; Keivany and Soofiani 2004; Soofiani et al. 2006; Asadollah et al. 2011; Keivany et al. 2012; Abaszadeh et al. 2013; Ghanbarzadeh et al. 2014, 2017; Keivany and Daneshvar 2015; Kiani et al. 2016; Keivany and Siami 2020).

The mean condition factor of female specimens was higher and was recorded in May. In C. damascina from the Zayandehrud River it was observed in August (Asadollah et al. 2011) (Table 5). Condition factor is an index reflecting interactions between biological and non-biological factors in fish physiology. It is used to compare different populations in different conditions and life cycles (Bagenal and Tesch 1978). In summary, this fish is a relatively slow growing species with an isometric growth pattern and the maximum age of 7 years, the maximum length of $21 \mathrm{~cm}$ and the maximum weight of $188 \mathrm{~g}$.

\section{ACKNOWLEDGEMENTS}

We would like to thank Dr. S. Asadollah and Mr. E. Motaghi for their help in fieldwork. The authors declare that there is no conflict of interest. This research was financially supported by Isfahan University of Technology and has been approved by IUT Ethics Committee.

\section{REFERENCES}

Abaszadeh, A., Y. Keivany, N. M. Soofiani, and A. Falahatimarvast. 2013. Reproductive biology of the greater lizardfish, Saurida tumbil (Bloch, 1795), in Bushehr coastal waters of Iran. Turkish Journal of Zoology 37 : 717-722.

Abdoli, A., and H. Mostafavi. 2009. Preliminary investigation of some biological characteristics of Capoeta 
damascina in Daleki and Shahpour rivers, Boushehr Province, Southern Iran. Research Project, Institute of Environmental Sciences, Shahid Beheshty University, Tehran, $57 \mathrm{pp}$.

Abdoli, A., P. Rasooli, and H. Mostafavi. 2008. Length-weight relationships of Capoeta capoeta capoeta (Gueldenstaedt, 1772) in the Gorganrud River, south Caspian Basin. Journal of Applied Ichthyology 24: 96-98.

Al-Hussaini, A. H. 1949. On the functional morphology of the alimentary tract of some fish in relation to differences in their feeding habits: anatomy and histology. Journal of cell Science 3: 109-139.

Asadollah, S., N. M. Soofiani, Y. Keivany, and M. Shadkhast. 2011. Reproduction of Capoeta damascina, a cyprinid fish, in Zayandeh-Rud River, central Iran. Journal of Applied Ichthyology 27: 1061-1066.

Asadollah, S., N. M.Soofiani, Y. Keivany, and R. Hatami. 2017. Age and Growth of the Mesopotamian Barb, Capoeta damascina, in Central Iran. Iranian Journal of Fishery Sciences 16 (2): 511-521.

Bagenal, T., and F. Tesch. 1978. Age and growth. InMethods for assessment of fish production in fresh waters, edited by F. Bagenal, 365. IBP Handbook 3, Blackwell Scientific Publications, Oxford Press.

Bertalanffy, L. 1938. A quantitative theory of organic growth. (Inquiries on growth laws). Human Biology 10: 182-213.

Biswas, P. 1993. Manual of methods in fish biology. South Asian Publisher put Ltd., 105-107 pp.

Esmaeili, H. R., and M. Ebrahimi. 2006. Length-weight relationships of some freshwater fishes of Iran. Journal of Applied Ichthyology 22: 328-329.

Esmaeili, H. R., H. Mehraban, K. Abbasi, Y. Keivany, and B. Coad. 2017. Review and updated checklist of freshwater fishes of Iran: Taxonomy, distribution and conservation status. Iranian Journal of Ichthyology 4 (Suppl. 1): 1-114.

Fishelson, L., M. Gren, J. Van Vuren, and R. Manelis. 1996. Some aspects of the reproduction biology of Barbus spp. and Capoeta damascina and their hybrids (Cyprinidae, Teleostei) in Israel. Hydrobiology 317: 79-88.

Ghanbarzadeh, M., N. M. Soofiani, Y. Keivany, and S. A. Taghavi-Motlagh. 2014. Use of otolith length and weight in age estimations of the kingsoldier bream, Argyrops spinifer, in the Persian Gulf. Iranian Journal of Ichthyology 1 (1): 1-6.

Ghanbarzadeh, M., Y. Keivany, and N. M. Soofiani. 2017. Population dynamics of the sparid fish, Argyrops spinifer (Teleostei: Sparidae) in coastal waters of the Persian Gulf. Iranian Journal of Sciences Technology 41: 313-319.

Gharache, M. 2008. On the biology of Capoeta damascina in qanat of southern Isfahan Province central Iran. BSC Project. Gonbad Higher Education Center, Gonbad, Iran, $75 \mathrm{pp}$.
Hasankhani, H., Y. Keivany, H. Raeisi, M. Pouladi, and N. M. Soofiani. 2013. Length-weight relationships of three cyprinid fishes from Sirwan River, Kurdistan and Kermanshah provinces in western Iran. Journal of Applied Ichthyology 29: 1170-1171.

Hile, R. 1936. Age and growth of the cisco, Leucichthys artedi (Le Sueur), in the lakes of the northeastern highlands, Wisconsin. US Government Printing Office.

Johal, M. S., H. R. Esmaeili, and K. K. Tanadon. 2001. A comparison of back-calculated lengths of silver carp derived from bony structures. Journal of Fish Biology 59: 1483-1493.

Johari, S. A., B. W. Coad, S. Mazloomi, M. Kheyri, and S. Asghari. 2009. Biological and morphometric characteristics of Capoeta fusca, a cyprinid fish living in the qanats of south Khorasan, Iran (Osteichthyes: Cyprinidae). Zoology of Middle East 47: 63-70.

Kalkan, E. 2008. Growth and reproduction properties of Capoeta trutta (Heckel, 1843) in Karakaya Dam Lake. Turkish Journal of Zoology 32: 1-10.

Keivany, Y., and E. Daneshvar. 2015. Reproduction of an isolated Iranian cichlid, Iranocichla hormuzensis. Caspian Journal of Environmental Science 13 (2): 119-128.

Keivany, Y., and M. Siami. 2020. Age and growth of a newly described barb, Capoeta coadi (Cyprinidae), in Beheshtabad River, Tigris basin. International Journal of Limnology 56: 1-8.

Keivany, Y., and N. M. Soofiani. 2004. Contribution to the biology of Zagros tooth-carp, Aphanius vladykovi, in central Iran (Cyprinodontidae). Environmental Biology of Fishery 71: 165-169.

Keivany, Y., P. Zare, and L. Kalteh. 2012. Age, Growth and Reproduction of the Female Kutum, Rutilus kutum (Kamensky, 1901) (Teleostei: Cyprinidae), in Gorgan-Rud Estuary, Northern Iran. Research of Zoology 2: 7-14.

Keivany, Y., M. Nasri, K. Abbasi, and A. Abdoli. 2016. Atlas of inland water fishes of Iran. Iran Department of Environment Press, 218 pp.

Keivany, Y., M. Ghorbani, and F. Paykan Heyrati. 2017. Age and growth of Alburnus mossulensis (Cyprinidae) in Bibi-Sayyedan River of Isfahan Province. Iranian Journal of Fisheries Sciences 16 (4): 1164-1177.

Keivany, Y., S. S. Mortazavi, and O. Farhadian. 2018. Age and growth of brond-snout, Chondrostoma regium in Beheshtabad River of Chaharmahal \& Bakhtiari Province of Iran (Teleostei: Cyprinidae). Iranian Journal of Ichthyology 5 (1): 30-42.

Khalaf, G. 1987. Le cycle sexuel de Capoeta damascina (Cyprinidae) dans les cours d'eau libanais. Cybium 11: 395-401.

Kheyrandish, A., A. Abdoli, and L. Abdoli. 2014. Age and growth of Capoeta damascina (Valenciennes in Cuvier and Valenciennes 1842) in Daleki River of Boushehr province. Journal of Animal Research 26: 425-434. 
Kiani, F., Y. Keivany, and F. Paykan-Heyrati. 2016. Age and growth of king nase, Condrostoma regium (Cyprinidae), from Bibi-Sayyedan River of Semirom, Isfahan, Iran. Iranian Journal of Fisheries Sciences 15 (3): 1214-1223.

King, M. 1995. Fisheries Biology, Assessment and Management, Fishing News Books. Surrey, 341 pp.

Klumbs, R. A., M. A. Bozek, and R. V. Frie. 1999. Proportionality of body to scale growth: validation of two back-calculation models with individually tagged and recaptured smallmouth bass and walleyes. Transactions of the American Fisheries Society 128: 815-831.

Mazaheri, Z. 2007. Age and growth of Capoeta damascina in Zayande-Roud River Isfahan Province, Central Iran. BSc Project. Isfahan University of Technology, Isfahan, Iran, $85 \mathrm{pp}$.

Munro, J. L., and D. Pauly. 1983. A simple method for comparing growth of fishes and invertebrates. ICLARM 1: 5-6.

Nikolsky, G. V. 1963. The ecology of fishes. London: Academic Press, 352 pp.

Patimar, R., and B. Mohammadzadeh. 2010. On the biological characteristics of Capoeta fusca (Nikolskii, 1897) in eastern Iran. Journal of Applied Ichthyology 27: 873-878.

Patimar, R., and S. Farzi. 2011. Life history, and other biological traits of the trout barb Capoeta trutta in the River Meymeh (western Iran). Folia Zoologia 60: 153-158.

Patimar, R., E. Ownagh, N. Jafari, and M. Hosseini. 2009. Intrabasin variation in allometry coefficients of lenkoran Capoeta capoeta gracilis (Keyserling, 1861) in the Gorganroud basin, southeast Caspian Sea, Iran. Journal of Applied Ichthyology 25: 776-778.

Pauly, O. 1984. Fish Population Dynamics in Tropical Waters: a Manual for Use with Programmable Calculators. ICLARM Studies and Reviews 8: 325.

Pauly, D., and J. L. Munro. 1984. Once more on the comparison of growth in fish and invertebrates. Fishbyte 2: $1-21$.

Pitcher, T. J., and P. J. B. Hart. 1982. Fisheries Ecology. London: Croom Helm, 416 pp.
Poria, M., A. Abdoli, M. Kazemian, F. Nouri, K. Ghanbari, and F. Ejraei. 2014a. Study of reproductive characteristics of Capoeta trutta in Gamasyab River, Kermanshah Province, Iran. Internal Journal of Biosciences 4: 39-46.

Poria, M., A. Abdoli, F. Nouri, K. Ghanbari, Y. Ghiasi, and A. Fatahi. 2014b. Study of reproductive characteristics of Capoeta trutta in Alvand River, Kermanshah Province, Iran. Journal of Biodiversity Environmental Sciences 4: 128-134.

Qasim, S. Z. 1966. Sex ratio in fish populations as a function of sexual differences and growth rate. Current Science 35: 140-142.

Rezaei, M. M., A. Kamali, B. H. Kiabi, and A. Shabani. 2007. Growth and reproduction of Capoeta capoeta gracilis in Golestan National Park compared with data provided before 2001. Iranian Fisheries Science Journal 2: 63-73.

Ricker, W. E. 1975. Computation and interpretation of biological statistics of fish populations. Journal of the Fisheries Research Board of Canada 191: 1-382.

Siami, M., Y. Keivany, and O. Farhadian. 2017. Reproductive characteristics of Siahmahi, Capoeta damascina (family Cyprinidae), in Beheshtabad River, Tigris basin. Sri Lanka. Journal of Aquatic Sciences 22: 21-27.

Skryabin, A. G. 1991. The biology of stone loach Barbatula barbatulus in the Rivers Goloustnaya and Olkha, East Siberia. Journal of Fish Biology 42: 361-374.

Soofiani, M. N., and S. Asadollah. 2010. Some aspects of the growth and reproduction of (Capoeta damascina Valenciennes, 1842) from the Hanna Wetland, Semirum. Iranian Scienific Fisheries Journal 18: 145-156.

Sparre, P., E. Ursin, and S. C. Venema. 1989. Introduction to Tropical Fish Stock Assessment. Part 2. Manual, FAO fisheries technical paper, Rome.

Stoumboudi, M. T., W. Villwock, J. Sela, and M. Abraham. 1993. Gonadosomatic index in Barbus longiceps, Capoeta damascina and their hybrid (Pisces, Cyprinidae) versus spermatozoan index in the parental males. Journal of Fish Biology 43: 865-875.

Wooton, R. J. 1998. Ecology of teleost fishes. London, UK: Chapman and Hall, 245 pp. 